\title{
GOMMENTARIES
}

\section{LYING TO CLIENTS FOR ECONOMIC GAIN OR PATERNALISTIC JUDGMENT: A PROPOSAL FOR A GOLDEN RULE OF CANDOR}

\author{
Carrie Menkel-Meadow $\dagger$
}

\section{INTRODUCTION}

Lisa Lerman's article, Lying to Clients, ${ }^{1}$ raises very important questions and answers them in part. She asks if the provisions of the ethical codes prohibit lawyers from ever lying to their clients, ${ }^{2}$ why do lawyers lie (she tells us with exploratory empirical data that they clearly $\mathrm{do}^{3}$ ), and in what circumstances can they justify such behavior.

Her reports from twenty interviewed lawyers ${ }^{4}$ tell us that lawyers are most likely to deceive clients in trying to get business (puffing or exaggerating their expertise and experience), keeping business (failing to disclose their mistakes, "falsely" impressing clients, failing to disclose accurately the progress of work, and engaging in strategic deception in casework), and making money from business (billing practices). She reviews the justifications that might be offered for such deceptive practices, adopting a philosophical, if not economic, cost and benefit analysis, by analyzing the harms and benefits "caused" by such deception. She engages us briefly in the important professional ethics issue of whether specific regulation or

† Professor of Law, University of California, Los Angeles; Acting Co-Director, UCLA Center for the Study of Women. A.B. 1971, Barnard College, J.D. 1974, University of Pennsylvania. Thanks to Robert Meadow and David Dolinko for their critical comments and suggestions.

1 Lerman, Lying to Clients, 138 U. PA. L. Rev. 659 (1990).

2 See Model Rules of Professional Conduct Rules 8.4, 1.4, 2.1 (1983); Model Code of Professional Responsibility DR 1-102 (A)(4) (1981).

3 See Lerman, supra note 1, at 705-44.

4 A group that hardly can be called a sample of anything other than some lawyers who agreed to talk about lawyer deception. The numbers are small; the lawyers may easily represent a biased group-those willing to talk about some forms of deception. Professor Lerman calls this "casual empiricism." As a social scientist, I prefer to call this an exploratory study. 
hortatory standards are best suited to encouraging good behavior on the part of lawyers.

Professor Lerman concludes her discussion of these issues with some suggested new ethical rules that would require greater candor than lawyers seem now to be providing, particularly with reference to their billing practices, ${ }^{5}$ their self-presentation for purposes of obtaining clients, ${ }^{6}$ and their reports to clients about the progress of work for which they have contracted. ${ }^{7}$ She also suggests that rules about reporting ethical violations should be modified. Rather than requiring lawyers to "snitch" on each other to disciplinary committees, ${ }^{8}$ they should instead confront each other, with the lawyer perceiving the ethical violation suggesting alternative courses of action. ${ }^{9}$ I think these suggestions are sound and I would support them, if asked to, by the appropriate disciplinary legislative body in my state. ${ }^{10}$

5 See Lerman, supra note 1, at 749-52.

6 See id. at 753-54.

7 See id. at 755-56.

8 See Model Rules of Professional Conduct 8.3; Model Code of Professional RESPONSIBILITY DR 1-103(A).

9 See Lerman, supra note 1, at 756-57. Professor Lerman suggests that if one lawyer is junior to another the duty to confront can be transferred to another, more senior member of the firm. Though it is beyond the scope of this Comment, the question of responsibility for the conduct of lawyers within the supervisory chain is an important one, demanding further consideration. In drafting the Model Rules, the Kutak Commission provided junior lawyers with the "defense" that they relied on "reasonable resolution of an arguable question of professional duty," MoDEL RuLE 5.2(b). The junior lawyer thus is offered the defense in any subsequent disciplinary proceeding that she "was simply following orders" (and ethical rules!). I disagree with this hierarchical and allegedly "more realistic" approach to legal decisionmaking because it inscribes a lack of professional responsibility in servility to law firm stratification. As a teacher of professional responsibility, I find this approach particularly troubling because I see the most junior lawyers, who have been educated after Watergate and subject to new $\mathrm{ABA}$ standards requiring instruction in professional responsibility, as the most equipped to make sound ethical judgments. See ABA Standards for Approval of Law Schools Standard 302(a)(iv)(1988). The junior lawyers not only know the rules much better than their seniors, but they may be better able to detect ethical conflicts because their attachments to important clients tend to be weaker.

10 Although the ABA "promulgates" ethical rules, these do not have the force of law unless the appropriate state body enacts them into law. In some states this is the Supreme Court, in others the legislature and in still others the State Bar itself, or some disciplinary committee is delegated such authority. In California, all of these bodies play some role in ethical regulation. See Cal. Rules of Prof. Conduct Rule 1-100 (West 1989) (adopted by the State Bar and approved by the State Supreme Court pursuant to statutory authority); Cal. Bus. \& Prof. Code $\$ \S 6067-68,6100$ 18, 6125-33, 6150-55 (West 1974 \& Supp. 1989) (statutes regulating, respectively, the attorney's oath and duty, authority of Supreme Court to discipline attorney, unlawful practice of law, and unlawful solicitation of legal business). 
Nevertheless, I believe there are other important issues about lying to one's clients that Professor Lerman has not discussed in her article which deserve attention. Underlying Professor Lerman's analysis is the acceptance and recognition of law as business ${ }^{11}$ and the need to adopt, as it were, "fair business practice acts," which is how I read her proposals. This is important because, in this era of deregulation, law appears to be a business sorely needing regulation. ${ }^{12}$ On the other hand, law remains a profession as well, one that is still called "learned" by some nostalgics like myself who believe that standards of honesty and candor should be higher than what we might tolerate as a fair business practice in the open market.

In this Comment, therefore, I will suggest that in addition to Professor Lerman's conceptualization of the ethics implicated in economic market aspects of lawyering, there may be other issues we should look at, as well, in assessing when and about what lawyers may "lie," "mislead," or "deceive" their clients. ${ }^{13}$ My aim here is twofold-to express a simple moral standard for analyzing lawyer

11 There is nothing new about this observation. Several recent articles in the National Law Journal and American Lawyer reported on such items as partner incomes, rankings of law firms in terms of billings, size, etc. A recent outpouring of more systematic scholarship has sought to understand changes in legal practice in terms of both demographics and economics. See, e.g., Sander \& Williams, Why Are There So Many Lawyers? Perspectives On A Turbulent Market, 14 Law \& Soc. INQuIRY 431 (1989) (demographic analysis); Galanter \& Palay, The Transformation of the Large Law Firm (paper presented to American Bar Foundation Conference on Professionalism, Ethics and Economic Change, September, 1988) (on file with University of Pennsylvania Law Review).

12 Law is big business, accounting for about $1 \%$ of the total United States Gross National Product-approximately 54 billion dollars worth of business per year as of 1986 (making it larger than the steel and textile industries and comparable to auto manufacture and publishing). See Sander \& Williams, supra note 11, at 434.

13 The majority of Professor Lerman's interviews focus on dealings with individual, fee-paying clients. See Lerman, supra note 1, at 703-44. Many lawyers, however, are on a salary paid by third parties, such as those who are employed by legal aid programs, public interest firms, governmental entities, and pre-paid insurance plans. See C. Serron, Managing Legal Services: The Transformation of Small-Firm Practice (paper presented to American Bar Foundation Conference on Professionalism, Ethics, and Economic Change, September, 1988) (discussing prepaid insurance plans) (on file with University of Pennsylvania Law Review). To the extent that those lawyers deceive their clients, the subject matter of their lies and their reasons for lying may be quite different. For the importance of context in affecting lawyer decisionmaking, see C. Menkel-Meadow \& B. Moulton, Who Decides? Lawyer-Client Decision-Making About Dispute Resolution, in Beyond the Adversarial Model: Materials and Cases on Negotiation and Mediation (forthcoming) (manuscript on file with the Universily of Pennsylvania Law Review). Professor Lerman herself points out that the dynamics between institutional, rather than individual, clients and their lawyers may also affect the ranges of candor. see Lerman, supra note 
liars ${ }^{14}$ that can be debated on moral, as well as policy terms, and second, to discuss briefly a number of "lying" issues that may be overlooked when a market model of lawyering is adopted. ${ }^{15}$

\section{A Simple Standard for Lying: The Golden Rule of CANDOR}

Professor Lerman offers as a rule the proposition that lawyers should never deceive clients for any reason of self-interest. ${ }^{16}$ I certainly agree with this rule, but I believe it fails to cover other types of lawyer lies which are also undesirable. Therefore, I propose a broader rule of conduct: lawyers should in all respects deal with their clients in the way they themselves would want to be treated if they were in the client's position. This rule goes further than do Professor Lerman's economic regulations in dealing with both economic and non-economic deception of clients (such as strategic deception during the course of case handling), but I think it presents more complex problems of philosophical justification and practical enforcement, and therefore offer this standard for further discussion and debate. To see the advantages of this broader rule over Profes-

1, at 665 n.20; see also Nelson, Ideology, Practice and Professional Autonomy: Social Values and Client Relationships in the Large Law Firm, 37 STAN. L. Rev. 503 (1985).

Lerman suggests that what she is most interested in is lawyers' selfinterestedness-their interest in income and reputation. See Lerman, supra note 1, at 667. Furthermore, Professor Lerman states that the twenty lawyers she interviewed about deceptive practices dealt more often with "process" concerns than "substance"-process having to do with work habits and billing practices. See id. at $670 \mathrm{n} .41$. Query whether this is really where the "deceitful" action is or whether the lawyers were more willing to own up to it as a more "acceptable" or common form of lying in the recognized competition to get business.

Lerman states that the thrust of her arguments are based on the failure of many professional responsibility writers to take account of the principal lawyer-client conflict-the lawyer's "profit motivation." Id. at 671.

14 It has become a common professional responsibility teacher's pun to adopt (or fully utilize if one already has one) a slightly southern accent to demonstrate how short an oral distance we must travel to go from "lawyer" to "liar."

15 I have long been interested in how non-market lawyering differs from market or fee-paid-for-service lawyering, not only in terms of ethical strictures but in lawyer decisionmaking and resource allocation. See Menkel-Meadow \& Meadow, Resource Allocation in Legal Services: Individual Attorney Decisions in Work Priorities, 5 LAw \& Pol'y Q. 237 (1983); see also Tremblay, Toward A Community-Based Ethic for Legal Services Practice, (forthcoming 37 UCLA L. Rev.) (1990) (forthcoming) (how different nonmarket contexts, such as the provision of legal services for the poor, may require different decision rules and "ethical" judgments in resource allocation by lawyers); Bellow \& Kettleson, From Ethics to Politics: Confronting Scarcity and Fairness in Public Interest Practice, 58 B.U. L. Rev. 337 (1978).

16 See Lerman, supra note 1 , at $684-85$. 
sor Lerman's rule, I will first examine the rationale for her rule and then consider why her rule will not adequately protect client interests in all situations.

\section{A. What's Wrong with Lying? Economic Self-Interest}

Professor Lerman begins her article with several definitions and degrees of lying or deceitfulness. Adopting Sissela Bok's definition ${ }^{17}$ that lying is stated untruthfulness and deception is a broader category of deliberate efforts to mislead which can occur by misstatements, non-verbal conduct, and even by silence, Professor Lerman concludes that what is crucial is the intent to deceive. Of course, the law currently examines intent when proscribing deception in real estate sales, commercial practices, ${ }^{18}$ and securities trading. In some areas the law has gone further and creates liability for "negligent misrepresentation," even without intent to deceive. ${ }^{19}$ Thus, even "unintentional" deception, may, in some circumstances, be something we will penalize. Most of this "commercial" regulation is designed to protect against economic harm. We assume that if the purchaser knew what the seller failed to disclose or actually lied about, the purchaser would not have made the deal, or at least might have bargained for a better price. Thus, the harm is the "unjust enrichment" of the lying or deceiving seller.

This fairly traditional conception of harm is what underlies Professor Lerman's discussion of the harm caused by lying lawyers. Since her interviewees lie most often out of economic self-interest, by padding their bills, exaggerating (in either direction depending on the circumstances) the amount of time and effort put into their work, and puffing about their experience and expertise, ${ }^{20}$ we come to see a picture of clients who are paying more than they should for legal services and perhaps also (though this cannot really be concluded from the data Lerman presents) getting either too little or too much service. Lerman concludes with a fairly simple rule: "Self-

17 See S. Bok, Lying: Moral Choice in Public and Private Life 14 (1978).

18 See, e.g., CaL. Cív. Code $\S 1572$ (West 1982) (making actual intent to deceive an essential element of an action for fraud).

19 See, e.g., Cal. Crv. Code $\$ 1710(2)$ (West 1985) (proscribing negligent misrepresentation as a category of deceit, as contrasted to intentional fraud (Cal. Civ. Code $\S 1572)$ ). A new statute requires affirmative, specific disclosures in real estate transactions and provides penalties and civil causes of action for failure to affirmatively disclose regulated matters. See CAL. Crv. Code $\S 1102$ (West Supp. 1989).

20 See Lerman, supra note 1, at 706-20; 721-23. 
interested deception of clients by lawyers should be prohibited",21 where self-interest appears to be equated with economic self-interest. Deception for such purposes is bad, she says, because lawyers will "appear greedy, immature, and unable to manage their time or face up to their mistakes."22

Is it only the "appearance" of greed with which we are concerned or is actual greed the real issue? Why is deception for selfinterest objectionable, both in the professional context as well as in the more general human context? Given the regulation of honest disclosure in many commercial transactions, is there any reason to exempt the professional-client relation? Indeed, many would argue that law in particular should not be a sharp practices, anything-themarket-will-bear, sort of business precisely because there is something unseemly about a "helping" profession maximizing profits from the legal "pains" of their clients?23 In other words, while I completely agree with Professor Lerman that lawyers should not deceive out of self-interest, the rationales for such a moral belief seem much deeper than they appear here. To the extent that deceiving another is considered "unfair" in our economic and legal system, we need to look at what unfair practices are punished and which are not. Professor Lerman's proposed rules requiring lawyers to be truthful in their billing practices and product (or service) advertisements seem entirely consistent with our general approach to fair trade practices in commercial transactions generally. Thus, they should hardly seem controversial. Lawyers, in their economic capacities, should be treated no differently than other producers of products or providers of services.

Our economic and moral system seems, as Professor Lerman points out, to be process-based. Let consumers have as good information as we can provide at the beginning of transactions, but we will not insure that everyone actually makes a fair deal, the rules seem to be saying. Such a morality explains why some of the proposals for new ethics rules, which would have required the prevention of

21 Id. at 685 .

22 Id.

23 This is, of course, exactly what lawyers (and doctors) do. Contingent fees in personal injury cases are the most obvious examples, but all fees derived from litigation can be seen this way. Is it therefore morally better or more excusable to make more money from a client's profitable transaction (a percentage of a successful deal)? What if the deal goes bad? It is commonplace for journalists to report the large legal fees in failed deals (such as United Airlines recent failed take-over, and the many bankruptcies that do not result in successful reorganization). 
"unconscionable" transactions by lawyers, ${ }^{24}$ ultimately failed. Thus, if lawyers honestly disclose their billing practices and fees, the substance of the deal made will be scrutinized only in the most extreme cases. ${ }^{25}$ Thus, Professor Lerman's proposed regulations for honesty in billing and economic matters seem premised on conventional principles of commercial and consumer transactions, as evidenced by our movement in legal development from caveat emptor to caveat venditor. The proposals here do nothing more than track the legal developments of commercial regulation.

\section{B. When Is Lying Justified: A Paternalistic Determination of Benefits and Harms to the Client}

In moving from the application of consumer law principles to the analysis of the economic relation between lawyer and client, Professor Lerman asks under what circumstances can lawyers lie to their clients. She suggests a commonly articulated utilitarian justification for some deceptions - the benefit to the client that occurs as a consequence of the deception is greater than the harm. Thus, we have "altruistic deception."26 Lawyers seem to justify their "misstatements" about the progress of a legal matter by suggesting that they are helping their clients avoid needless worry about the progress of their case. ${ }^{27}$ Here we face several difficulties. What if some "benefit" to the client can be rationalized to protect or coincide with a selfinterested motive of the lawyer, such as in the progress report example above? Benefits and burdens do not always fall so neatly and symmetrically on opposite sides of the ledger.

More problematic, however, is the determination that must be made about what benefits the client and who makes judgments about those benefits. Professor Lerman discusses two examples taken from

24 See Model Rules of Professional Conduct Rules 4.2, 4.3 (Discussion Draft, Jan. 30, 1980), which would have required lawyers to be "fair" in dealing with other participants to a negotiation and would have prevented a lawyer from participating in or assisting another in participating in an unconscionable agreement.

25 See Model Code of Professional Responsibility DR 2-106 (1981) (prohibiting the charging of "clearly excessive fees"); EC 2-17 (should not charge more than a reasonable fee); EC 2-19 (should discuss and agree with client on basis of fees in advance); Model Rules of Professional Conduct Rule 1.5(a) (1989) (fees must be reasonable and basis of fee must be disclosed at outset of the representation).

26 An analysis along this consequentialist line of reasoning persuades many philosophers, including Sissela Bok, that at least some lying is justified-such as lying to avoid harm to others or even to cause benefits, if no other is harmed.

27 See Lerman, supra note 1, at 684. 
outside of the economic emphasis of her article. The lawyer who decides not to pass on "nasty" remarks made by a spouse during divorce proceedings may be withholding information, but does so to prevent greater harm (insult, aggravation, hurt) to the client. Might not the motivation also be that if the client knew of the nasty remark she might want to respond and cause more (acrimonious) work for the lawyer? What if the client actually would decide to settle the case because she wanted no further dealings with the "nasty" spouse? Thus, the lawyer's judgments about sparing the client from hearing "bad" information might have ramifications for how the case is pursued. The substance of the case and how it is handled cannot be separated from the information in question. In giving the client the "benefit" of not hearing painful information, the lawyer also usurps the client's ability to make judgments about how she wants her case handled. Note here that the lawyer's monetary interest might not be consistent with other "self-interests"- the lawyer might make more money from the additional work (depending on the fee arrangements) but might find the work unpleasant. ${ }^{28}$

Professor Lerman suggests that in such cases lawyers and clients can contract for the withholding of information in advance (a further inscription of the market model of lawyering). But, can they possibly know in advance what information will need to be withheld to avoid harm to the client? If the lawyer is in doubt who should she ask? The client? A family member? Another lawyer?

In another example (one that I too encountered in practice), the lawyer learns that the client has a terminal illness (in a social security disability case) and the doctor has decided not to inform the client/ patient. ${ }^{29}$ Who decides whether to inform the client-the lawyer, the doctor, the client's relatives (assuming there are some-in my case there were not)? What is the harm/benefit to the client in learning about impending death?

Both of these cases involve paternalism, perhaps beneficently motivated paternalism, ${ }^{30}$ but paternalism none the less. How is the

28 This depends on where the lawyer practices. In Los Angeles County, where I teach, practice, and live, many seem to think divorce lawyers revel in and indeed increase the acrimony in divorce. See Nasty, Nasty, Nasty: High Profile Divorce Wars Are Symbols of What Has Become A Tough Era for Relationships, L.A. Times, Dec. 8, 1989, at E1 .

29 See Lerman, supra note 1, at 684 n.92.

30 I use the more common phrase paternalism here for this familiar concept but note the gendered aspect of this term. The phrase maternalism often connotes different emphases in such decisionmaking. See generally C. Gilligan, IN A Different Voice (1982); S. Ruddick, Maternal Thinking (1988); Menkel-Meadow, Portia In A 
lawyer who decides to withhold information to avoid harm to the client to be judged or second-guessed? Are there different standards for professionals in such situations than would be applied to any person who has information about another human being that might be shared with that person?

As one guideline, I am reminded of one of my favorite moments in professional socialization. Sometime in the early 1960s, on the Doctor Kildare television program, young Doctor Kildare asks old and wise Dr. Gillespe whether he should truthfully tell a patient she has a terminal disease. Dr. Gillespe offers the following tip: If the patient asks "Am I going to live, doctor?" the patient wants to live and should not be told of imminent death; if the patient says "I'm going to die, aren't I doctor?," the patient is a realist who can take it, and you can tell the truth. ${ }^{31}$ Here, the experienced professional paternalist seems to be advising Doctor Kildare, based on his many years of experience-he knows what messages patients really convey with their questions. He can save Doctor Kildare much time and angst by decoding their needs and wants for them. As an incipient patient I learned my lesson well-if ever I wanted the truth from my doctor I would have to convince her I could "handle" it.

This approach did not help me with my own dying client in the social security disability case. She lived alone in a large city. I did not think she could "handle" it-but I thought she had the right to decide how to spend her last remaining months on earth. As a lawyer I wanted her to understand the significance of the hearing she had to go to and that she might have wanted to make a will. (Ultimately her hearing was called off-her case was so clear she received her disability benefits on the paper record. She died two months later. I felt closer to her than many of my clients because we had shared this terrible human moment of mortality). Did I make the right decision?

Different Voice: Speculations On a Women's Lawyering Process, 1 Berkeley WoMEn's L.J. 39 (1985).

31 These are not exact words, but my own recollection of them. The point of this anecdote is that it demonstrates how relative and contextual our judgments about truth telling might be. Given medical advances and changes in therapies, including biofeedback, the patient who wants to live might now be told the truth under Gillepse's system of morality: if knowing the gravity of the illness induces the patient to take her recovery into her own hands, the chances of actually recovering are much greater. See, e.g., N. Cousins, ANatomy of AN ILlNess 34-48 (1979). Medical research about terminal illness indicates that over a twenty-five year period, practices about truth-telling have changed radically. Now over $70 \%$ of physicians surveyed do tell their patients while only twenty-four years ago $82 \%$ did just the opposite. See Radovsky, "Occasional Notes: Bearing the News, 313 N. ENG. J. MED. 586 (1985). 
Is Doctor Gillespe right in deciding, as a doctor with many years of experience, that he knows what is best? The problem for me in any rule that allows us to do that which benefits or does not harm others is that it is ultimately a decision one makes for another and our basis for judging such decisions are unclear.

\section{The Golden Rule of Candor}

Paternalism in ethical codes and rules, as well as in lay action, must be justified morally. Thus, it seems that paternalism must be judged in part on the basis of who makes the paternalistic decision. In deciding whether or not the truth should be told, a lawyer, doctor, social worker, nurse, and yes, even a lay person, might begin with the inquiry: Would I want to be told this information if I were the client/patient? In one sense this inquiry violates Professor Lerman's rule because the professional self is the referent. In that sense, decisions about whether to tell the truth are "self-interested."

Yet, I suspect this "self-interested" standard might lead to more truthtelling. In part, this depends on whether it is the lawyer as person who asks the question or whether it is the lawyer as professional who does. There may be more than one 'self' implicated. I propose such a standard because I think it will aid in resolving both the economic deception cases and cases in which lawyers engage in other forms of deception. In addition, I think such a standard would enable the lawyer to empathize with the client and take the client's needs in the relationship more seriously ${ }^{32}$ by causing the lawyer to have to imagine what it would be like to be in the client's shoes, for purposes of getting information.

Let's apply such a standard to the common problems Professor

32 This is a sort of irony in lawyer-client relations and in some sense turns the client-centered decisionmaking notion on its head. For discussions of the traditional client-centered approach, see D. Binder \& S. Price, Legal INTERviewing AND Counseling (1977); Maute, Allocation of Decisionmaking Authority Under the Model Rules of Professional Conduct, 17 U.C. Davis L. REv. 1049 (1984); $c f$. Ellman, Lawyers and Clients, 34 UCLA L. REv. 717, 753-58 (1987) (acknowledging fact that even lawyers who seek to be client-centered must sometimes manipulate their clients, and discussing various situations in which such manipulation might be justified). I have argued elsewhere that "client-centeredness" may not be appropriate in all cases, such as when clients are quite powerful and may dominate lawyers, for economic as well as other reasons, and in cases in which the lawyer might actually know more about a particular decision and its effects than a client (such as what dispute resolution device to use in some cases). See C. Menkel-Meadow \& B. Moulton, supra note 13. On the other hand, lawyer disclosure, based on a "lawyer-centered" notion of what should be disclosed, still can lead to client-centered decisionmaking-the client will usually have more information with which to make the decision. 
Lerman sets out. Would a lawyer want an accountant to bill honestly? Would she be willing to pay for "study hours"? (I would-I would rather have my accountant read all the recent tax regulations than rely on his "years of experience" in taking the proper deduction). Would a lawyer want a doctor to honestly (and not with puffery) state his expertise and experience? Professor Lerman's proposed regulations seem appropriate, whether or not one believes that ethical matters should be regulated by specific rules or precatory exhortations, because they apply to lawyers the sort of "truth-inlending, truth-in-advertising, truth-in-real-estate transactions" we now require in any number of transactions. Thus, lawyers should clearly disclose the truth with respect to their expertise, experience, billing practices, and progress of the case. As professionals who consume other professional services, lawyers should be particularly sensitive to such matters.

Would a lawyer want to know whether or not she is terminally ill? This decision is a more difficult and subjective one to make, but still likely, in most cases, to be answered yes. Lawyers in particular might want to be able to write wills and arrange their legal and other matters. It seems likely, however, that most people would want to know. ${ }^{33}$

I suspect as well that most lawyers would want the "nasty" words of an ex-spouse to be revealed to them. Even if painful, they are relevant both to legal and emotional decisions that a divorce client might be making. To the extent that a lawyer might want to caution a client not to take them too seriously in the context of acrimonious divorce proceedings, the lawyer can add additional words of advice and counsel to the reporting of the nasty words. Thus, to the extent that a lawyer feels a paternalistic desire to withhold information, it might be useful to share the reasons with the client as a way of dealing with what might be the benefits and burdens of disclosure and the client will be able to better understand the meaning of what has been disclosed.

Thus, I offer the proposed standard for considering when a lawyer ought to be candid with a client: Lawyers should reveal to their clients that which they would want revealed to them if they were clients.

What could be the objections to such a simple Golden Rule of

33 This is a problem that merits more consideration than it gets here. On the other hand, it needs to be considered in light of medical ethics and medical practice which have been changing since the days of Doctors Kildare and Gillespe (and the onslaught of AIDS and related diseases) to more forthcoming medical practices, leaving fewer lawyers with these dilemmas. 
Candor? I honestly cannot imagine any with respect to the kinds of economic self-interest issues raised by Professor Lerman and thus, to the extent that her proposed regulations seem to legislate such standards, I support them. Perhaps they seem so supportable to me because California has already begun to regulate with respect to fee disclosure (not exclusively in the ethical codes-in the Business and Professions Codes as well), requiring written documentation of fee arrangements, among other requirements. ${ }^{34}$

There might be objections to such regulations based on their enforceability, an argument Professor White used some time ago to justify the absence of stricter rules with respect to lying in the negotiation context. ${ }^{35}$ Here, the argument goes that if rules are not enforced, the credibility of the entire rule system may suffer as a result. Others, notably my colleague, Professor Murray Schwartz, have argued that rules that seek to achieve high aspirational standards express the best in the profession and tell us when we fall below those standards. ${ }^{36}$ Such rules would apply even to what Professor Lerman has called "altruistic" (economic) deception-the case of the lawyer that bills a paying client more and thereby subsidizes a pro bono activity. ${ }^{37}$ While such Robin Hood lawyering might seem

34 See Cal. Bus. \& Prof. Code $\$ \S 6146-49$ (West Supp. 1989) (providing various rules about fees and disclosures, and requiring that fee arrangements be in writing); Cal. Rules of Professional Conduct Rule 4-200 (1989) (prohibiting unconscionable fee agreements).

35 See White, Machiavelli and the Bar: Ethical Limitations on Lying in Negotiation, 1980 Aм. B. Found. Res. J. 926. Professor White's argument was that if rules go too far afield from generally accepted practice they will be disobeyed and decrease the effectiveness and credibility of all ethical rule systems. See id. at 937 . He also argued that the particular context of negotiation was so varied in different types of cases and in different regions of the country that it would be virtually impossible to create a uniformly acceptable standard of truthtelling in legal negotiations. See id. at 927 . In addition, Professor White argued that most negotiations are conducted privately and it would be difficult in many cases to uncover and prove situations of deceit. See id. at 926. This seems a logical argument from a distinguished commercial law scholar who has also studied the realities of commercial practice.

As a teacher of negotiation my own views are different from Professor White and closer to those of Professor Murray Schwartz and Judge Alvin Rubin. See infra note 36 and accompanying text (Schwartz' views); Rubin, $A$ Causerie on Lawyer's Ethics in Negotiation, 35 LA. L. REv. 577, 589 (1975) ("The lawyer must act honestly and in good faith."). In short, I think lawyers' lies to other lawyers ought also to be regulated and governed by Golden Rule standards but my exposition on that issue must await another day.

36 See Schwartz, The Death and Regeneration of Ethics, 1980 Am. B. Found. REs. J. 953, 963 ("Standards of performance that exceed the minimum, standards that set achievement goals, should be promulgated. They should be made known so that all lawyers can measure their conduct against them ....").

37 See Lerman, supra note 1 , at 709-10. 
noble to some, the lawyer as client would clearly like to know she is doing a noble thing by subsidizing pro bono work. Indeed, the client who is told about such opportunities might actually encourage it, either for the moral good of it or from the instrumental tax deductibility of it.

There are more difficult issues with some non-economic decisionmaking. Would a client like to be told everything about a particular procedure? Different people do have different values, desires, etc. about the need for detail or what might upset them. Consider whether the patient wants to know all the gruesome details of an operation and whether a client really wants to know all the details about the path to having a motion decided. Some lawyers might actually have different standards than their clients and thus application of their own values to their clients would be a particularly onerous sort of paternalism. Still, I think the expressions of paternalistic standards that suggest that the lawyer should try to figure out what is best for the client (as the lawyer determines it, even if the lawyer uses a client-centered counseling model ${ }^{38}$ ) frequently hide the fact that the lawyer inevitably is making judgments of her own. Doctor Gillespe's rule is expressly client-centered-it just abstracts clients into one of two categories. (What if the smart patient simply asks the doctor an open-ended question: "What is my fate?", "What illness do I have?", "How long will I live?", or "What's happening to me, doctor?"). Doctor Gillespe's rule obviously vests the decision whether to tell the truth in the doctor. Thus, my claim for a golden rule of truth at least provides a standard, albeit a subjective one, for judging whether the truth should be told. I believe that if lawyers truly confronted their self-interest as if they were clients, not lawyers, they would find the moral road in practice clearer (not necessarily easier. to practice).

The Golden Rule approach would clearly be objected to by those like Professor Ted Schneyer, who think that moral guidelines for behavior are inadequate in the legal ethics context and specific regulations are necessary. ${ }^{39}$ The standard I suggest is a particularly

38 In either its purest form, see D. BINDER \& S. PRICE, supra note 32, or its more manipulative form. See Ellman, supra note 32.

39 See, e.g., Schneyer, Moral Philosophy's Standard Misconception of Legal Ethics, 1984 Wis. L. REv. 1529, 1571 (arguing that "simply tinkering with ethics rules, or even with lawyers' moral sensibilities" will not counter the pressures on lawyers to unduly favor their clients over third parties, and that reformers should study "the constraints and incentives that operate on lawyers in various settings and ... [the] measures that might be taken to alter those constraints and incentives"). 
problematic one, precisely because of its subjectivity. As Professor Lerman points out, the implicit assumption in such objections is that without specific and enforceable regulation, lawyers will always choose the less ethical route. ${ }^{40}$

Whether a lawyer could use this double-visioned standard of considering herself a lawyer and client at the same time is difficult to assess. Aside from a sort of existential schizophrenia there may actually be cases where real role conflicts would get in the way. Would a recovering alcoholic lawyer disclose his condition to a client? As a client he might want to know, but being able to present himself as a sober professional might be essential to his recovery and effectiveness as an attorney. In other cases, there may be information only the lawyer knows is available because she is a lawyer (like some procedural matters), so it is the lawyer's knowledge qua lawyer that would have to be applied to the decision of whether to tell the client.

\section{The Other Lies That Lawyers Tell: Lying BEYOND THE MARKET}

Professor Lerman's focus on when and how lawyers lie to their clients is important and significant, and if her exploratory interviews could be replicated more systematically, we might learn whether lying about professional self-interest in the form of economics and reputation is in fact the most common form of deception. Before we

40 See Lerman, supra note 1 , at 749-50. This argument has never been persuasive to me. When I moved to California after some years of practice and teaching (including ethics) in another state (Pennsylvania) I had to sit for the Attorney's Bar Exam, which included the MPRE (Multi-state Professional Responsibility Exam). I was advised by a well meaning practitioner friend, in cases of doubt about a question, to pick "the second most ethical answer." His advice was that the rules never required "the most ethical" conduct because there was always a lawyer's loophole in the rules-like client consent to seemingly inappropriate behavior (as in conflicts of interests) or lawyer protection of self (in exceptions to the confidentiality rule). This has proved remarkably robust advice and actually provides a useful tip for many students studying the rules for the MPRE. The only questions whose answers are quite clear involve fees and escrow accounts (supporting Professor Lerman's proposals to regulate more clearly about billing and fee practices). The regulations, therefore, do not in my view insure "the most ethical" conduct and I think there are areas where we clearly need the kind of general moral guidelines that moral philosophers would have us consider. I cannot resist pointing out that the California Bar Examiners have decided that the MPRE has proven somewhat too mechanical for testing ethics. Beginning this year, in addition to the MPRE, the California Bar Exam now includes ethical questions on the essay portion of the exam so that test takers must explicate their ethical choices. If ethics is going to be on the bar, this seems the sensible approach to me and one that is consistent with the sort of discretionary rule I am proposing here. 
learn that, however, I would like to explore some of the types of deception that might occur in situations outside of the economic market for legal services to see whether the simple golden rule of truth will serve as a guide in those cases as well. Some of the situations described below may also occur in private practice and have implications for how such cases are handled, but they are not as directly related to the economic nexus between lawyer and client that is the focus of so much of Professor Lerman's article. In short, we might ask what distinguishes a lawyer lie from any other kind of service provider lie? What do lawyers in particular lie about that is different in content from how any businessperson might "lie" about their services or products?

The easiest cases are those in which issues in public or non-market lawyering are the same as in fee-for-service lawyering: deception to clients about progress on work (delay), misrepresentation of expertise or experience, failure to disclose mistakes made in work, and the kind of strategic deception that Professor Lerman describes when a lawyer inadequately prepares a witness in order to preserve spontaneity on the witness stand. ${ }^{41}$ To the extent that Professor Lerman's proposed regulations deal with these issues, they would clearly cover the government, salaried, or public interest lawyer. ${ }^{\mathbf{4 2}}$

More difficult are those issues which revolve around the fact that non-market lawyering may involve different kinds of clients-establishing who is being deceived may be more difficult. The district attorney who decides to authorize questionable drug arrests because this will enhance her visibility in the community and electorate (if she sits for elective office), even when she knows that many of the arrests will not "stick," deceives her client-_"the public." If the D.A. could think of herself as an individual member of the public, would that change her behavior? My guess is probably not. When the public is the client, the connection to the lawyer as public official seems attenuated and it is hard to conceive of one individual's view as making a difference. In addition, much of the public, and particularly a sophisticated lawyer member of the civic polity, might actually expect a certain amount of "deception" from political lawyers and public

41 See Lerman, supra note 1, at 736-37.

42 I have some difficulty in this context (perhaps in all contexts) with a requirement that lawyers return clients' phone calls in two days. See Lerman, supra note 1, at 756 (proposing modification to Model Rules of Professional Conduct Rule 1.4 (1983)). Who the "client" is in some non-market contexts will not be as clear (such as in class actions or representation of public agencies) and may require more than two days for response. 
officials. Moreover, in the political context, a variety of contested political justifications or interpretations of disputed law ${ }^{43}$ could serve to justify any number of such activities. Perhaps the fear of arrest might actually decrease some of the drug trade. Who is to say that following such a course is actually deceiving the public, even if the arrests do not lead to convictions?

As fee-for-service lawyers might deceive their clients by taking on cases that have little chance of success for economic reward, analogous issues apply in the non-market context where political pressure may cause a lawyer to take a case which she knows has little chance of success but which an important member of the political team would like initiated or defended. Here the Golden Rule of Candor may not help us because the lawyer as client might well understand why the suit is desired and would not want to know that it was likely to lose (there may be reasons other than winning that could motivate the lawsuit). Thus, the lawyer would be justified in withholding information about the likely outcome. In addition to posing ethical dilemmas of candor, these situations present versions of the "role morality" problem, long applied to lawyers, ${ }^{44}$ but also applicable to politicians and particularly to lawyer-politicians. Can occupants of particular roles in our society-lawyers, soldiers, politicians-defend their actions on the basis of what the role requires of them? ${ }^{45}$

Oddly enough, like the lawyer who wants to maximize income, the public interest lawyer who wants to maximize law reform or personal reputation ${ }^{46}$ may find herself in trouble with the Golden Rule of Candor. To the extent that the lawyer may use a different form of self-interest, usually expressed as altruistic or political interest, in bringing lawsuits to change rules or to enforce present ones, the Golden Rule of Candor would require such lawyers to fully disclose

43 Could a lawyer here argue that she was attempting to test the limits of the law or was advancing a claim "for the good faith argument for an extension, modification of reversal of existing law?" See Model Rules of Professional Conduct Rule 3.1 (1983); Model Code of Professional Responsibility DR 7-102(A)(2) (1981).

44 See Wasserstrom, Roles and Morality, in The Good Lawyer: Lawyers' Roles AND LAWYERs' ETHICs 26-27 (D. Luban ed. 1983) (discussing how lawyers escape criticism for using morally objectionable methods in representing clients because of the demands of their role).

45 See id.; Walzer, Political Action: The Problem of Dirty Hands, 2 Phic. \& PuB. Afr. 160,179 (1973) ("Moral rules are not usually enforced against the sort of actor I am considering, largely because he acts in an official capacity.").

46 See Menkel-Meadow \& Meadow, supra note 15, at 240-46 (discussing the factors that affect motivations of one group of non-market lawyers in performing legal work). 
their motivations to clients who may be acting in named representative capacity, such as in a class action. Without repeating the voluminous literature on the potential of the class action reform suit to "use" and "manipulate" clients, ${ }^{47}$ the danger here is of the lawyer who fails to fully disclose to the particular client all of the risks and benefits of such lawsuits. The most obvious conflict occurs when a settlement is offered to a particular client or named plaintiff as a way of "buying" off and dismissing the lawsuit. In my view, the Golden Rule would require no more than is already on the rule book-the lawyer must disclose all that might happen as best she can. Indeed, the use of the Golden Rule might actually facilitate candor for the lawyer would be free to say, "I think this is a very important matter and you could personally help the situation by participating in the lawsuit (and not settling). I might do the same thing if I were in your shoes." This forces the lawyer to be candid about his own "vicarious altruism" and to see if the client shares similar altruistic values. If not, the lawyer must also recognize when individual self-interest might lead the lawyer-as-client to want to settle. Such candor might actually increase the "mutual political commitment" leading to "comradeship" in the lawyer-client relationship ${ }^{48}$ that forms the basis of a golden rule in the first place-an empathetic understanding of the other, in this case across roles. On the other hand, in such public interest cases, applying the Golden Rule of Candor might be more difficult because of the particular power imbalance that exists, particularly in cases where clients are low-income or otherwise vulnerable and do not control the lawyer through economic interests. Here a lawyer even suggesting that "if a client" he would pursue a particular action, might be particularly hard for the client to resist. This is not really a problem of candor, however, but one of power relations and dominance in the professional role. Again the lawyer may have to be particularly vigilant to disclose more, rather than less, information to be sure the client understands as much as is possible what interests are to be served in the case and the actions taken within the case.

"Public" lawyers, those in the government and those fighting government, may also take advantage of another form of "deception"- using the media to "try" cases publicly and thereby manipulate results. This is a possibility for private market lawyers too, but access to the media may be greater in public interest cases. Here the

47 See, e.g., D. Luban, Lawyers and Justice: An Ethical Study 317-57 (1988).

48 These phrases are David Luban's. See id. at 324-25. 
lawyer deceives a general "client"-the public in the case of public lawyers-but may also go beyond her own client to manipulate or deceive the jury and the larger public as well. Such lawyers not only deceive their clients, but often bring their clients into the "deception" or manipulation by encouraging them to present themselves and their stories to the media for the purpose of self-interested gain in a lawsuit.

To the extent that public ${ }^{49}$ or public interest lawyers are supposed to be working for something other than the bottom line, their commitment to public service, fiduciary representation, and political and social change, their motivations may be different than those seeking monetary gain. ${ }^{50}$ Because lawyers, like all human beings, act to maximize self-interest, even if that self-interest is defined in altruistic terms, public and public interest lawyers may deceive their clients (and themselves) by attempting to maximize their nonmonetary goals. The ambitious prosecutor who manipulates cases and media to gain fame and the public interest lawyer who, instead of "cooling out" the client, ${ }^{51}$ encourages the client to pursue a claim on behalf of others, are both engaged in their own forms of lying to clients.

Lawyers may also deceive by silence in the advice they give their clients, not only in the obvious form of not stating their own views,

49 By "public" lawyers I mean those who work for the government and are thus invested with some notion of working for the public trust-an often amorphous and diffuse concept and clientele. This is to be distinguished in my view from public interest lawyers, though there is some overlap. Thus, prosecutors are clearly public lawyers, but some think they should be excluded from the public interest category when they act to enforce the status quo. The public interest lawyer is often, but not always, outside of a formal institutional structure and may or may not work for a salary. Most would include legal services lawyers and public defenders among the public interest bar, but these categories are fluid, controversial, and ever-changing.

50 The Milton Bradley game of Careers has always captured my sense of the different motivations lawyers bring to their diverse career goals and tasks. Early in the game players identify their own personal goals in terms of Hearts (love), Dollar Signs (money) and/or Stars (Fame), thus defining their own criteria of success. In the real world of legal careers it seems the public interest lawyers have chosen hearts and stars over dollars (perhaps a political symbol of a gavel or hammer should be added to provide the option of choosing social change).

51 This phrase comes from the sociologist Erving Goffman who used it in referring to the manipulation of prisoners and other "inmates" of social institutions. See E. Goffman, Strategic Interaction (1969); E. Goffman, Asylums (1961). The term has been applied to the practice of lawyers persuading clients to accept settlements, by manipulating or deceiving them into thinking their case is worth less than they think. See G. Bellow \& B. Moulton, The Lawyering Process: Materials for Clinical Instruction in Advocacy (1978). 
but by failing to express perspectives on the morality, ${ }^{52}$ as well as the prudence, of a particular course of action. Here the lawyer "deceives" by saying nothing when in fact she has a particular view about what should be done. While this form of deception undoubtedly exists in private representation as well, the cash nexus of the relationship might actually improve candor-a client who wants to "buy" the lawyer's opinion can probably extract it for a price. The client of the public lawyer has no equivalent leverage.

Like the private lawyers of big law firms, public lawyers are also subject to the context in which they work. Thus, the social structure of lawyering in large bureaucratic units ${ }^{53}$ may lead to organizational practices and routinization of tasks that may deter some forms of truth-telling and may reinforce a loss of "ownership" of lawyering activity. The rationale that "I was only following orders," may be as true in the large government office as in the private law firm.

It is beyond the scope of this Comment to explore all of the ways non-market lawyers deceive their clients. We need an exploratory study in this field, as Professor Lerman has done in the market context, ${ }^{54}$ before we can fully canvass the issues. I fear the dominance of the market economy in lawyering has begun to dominate our scholarship as well. ${ }^{55}$ This dominance may be the product of our increasing concern that law practice in its more aspirational forms is being corrupted by an increasing focus on the economic and business aspects of modern practice, ${ }^{56}$ and of our resulting desire to leg-

52 See Model Rules of Professional Conduct Rule 1.2(b) (1983) ("A lawyer's representation of a client . . . does not constitute an endorsement of the client's political, economic, social or moral views or activities."); MODEL CODE OF Professional Responsibility EC 7-8 (1981) ("Advice of a lawyer to his client need not be confined to purely legal considerations.").

53 See Schwartz, The Reorganization of the Legal Profession, 58 Tex. L. REv. 1269, 1284-89 (1980).

54 Professor Lerman states that her sample of 20 included some government lawyers, but virtually all of the examples she gives of deception are derived from the market, fee-for service context (the exceptions being communications to clients about the progress of work).

55 This is reflected not only in the focus on ethical issues in law firm practice, but in the move in legal profession studies to focus on the large law firm. See Galanter \& Palay, supra note 11, at 1-110 (discussing the growth and change at large law firms); Sander \& Williams, supra note 11, at 435-40 (same). Journalists with such publications as the National Law Joumal and the American Lawyer are obsessed with covering the large private law firm. Cf. Menkel-Meadow, Exploring a Research Agenda of the Feminization of the Legal Profession: Theories of Gender and Social Change, 14 Law \& Soc. INQUIRY 289, 306-08 (suggesting that legal scholarship on lawyers focus on other components of legal practice-such as women in the public sector).

56 Actually this fear about the commercialization of law practice is as old as the profession in the United States and the fears expressed today have their analogues in 
islate morality in the commercial sphere. I fear that regulation of the essentially commercial practices that Professor Lerman writes about-getting business (puffing), keeping business (misrepresenting work progress), and making profit from business (billing practices)-does not get at the heart of what should bother us about lying or deceiving clients. It may also represent a false security about "public-minded" lawyers, that because they do not have the financial incentives of the market, they do not deceive.

Thus, by exploring the deceptions of public, as well as private lawyers, we may get closer to what really should bother us about deception. It is not just that clients will be "bilked" out of their money and charged unfair prices, or will choose an incompetent lawyer, though these are real evils. What should concern us about lying lawyers, what really matters in other words, is that lawyers are supposed to be helping and caring professionals. If they are ultimately loyal to their clients, what does that loyalty consist of if it is based on a possibly mendacious relationship? Would we want someone who is not truthful to us to be representing us against the world? If the lawyer will lie or deceive the person she is serving, what will he do with those to whom he owes no loyalty-the lawyer on the other side, the judge, the larger world out there? If we can't trust our lawyers, whom can we trust?

Thus, ultimately the issue of lawyers lying to clients is one of trust and power, two relatively simple, but important concepts. If service is the ideal of the profession, should that service be considered appropriately carried out if the server decides what is good for the servee? What of the ultimate imbalance in a relationship in which the client is told to tell everything to the lawyer (and it will of course be kept confidential ${ }^{57}$ ) but the lawyer may not be telling everything to the client? This suggests that another form of the Golden Rule might be: The lawyer should be as truthful to the client as she expects the client to be with her. This formulation represents more fully the reciprocity imagined by the original Golden Rule. Is true reciprocity possible in a professional-client relationship? Are professional rela-

many earlier periods. Compare Commission on Professionalism, AMErican Bar Association, “. . . . In the Spirit of Public Service:" A Blueprint for the Rekindling of Lawyer Professionalism (1986) (recent concerns) with L. Friedman, A History of American LAw 634 (1973) (relating that during the Nineteenth Century the "organized profession" tried to "limited entry into the field, and (above all) tried to resist conversion of the profession into a 'mere' business or trade").

57 See Model Rules of Professional Conduct Rule 1.6 (1983); Model Code of Professional Responsibility Canon 4, DR 4-101 (1981). 
tionships inherently based on non-reciprocal promises or pledges, on a necessary form of paternalism? I think not, but until we can answer these questions, we will have to look more closely at the different places that lawyers and clients come together. Market lawyering is important, but it is not the whole story. To tell the story of economic lies (dare I call them little "green" lies) may be to avoid telling the story of more crucial lies (those that Professor Lerman's lawyers would not tell, or the stories of the lawyers who would not even agree to be interviewed).

\section{Conclusion: Pursuing Deceit or Extensions of the GOLDEN RULE}

Professor Lerman has attempted to make public a secret we all know-lawyers lie to their clients. She has informed us by using an exploratory, non-systematic, empirical method to uncover what lawyers say they lie about. (Might they have deceived the researcher?) They lie mostly about getting business, keeping business, and getting paid for business. There are lies about the process of legal practice (the terms of the relationship between lawyer and client) and lies about the legal judgments that are made within the substantive corners of a client's matter. Professor Lerman proposes some regulations to deal with these issues. I leave to others the inevitable arguments about whether these regulations will work or whether they need some re-drafting. In essence, I support them because they will make public and clear statements about punishable digressions from a standard of truthfulness we apply to other businesses.

What Professor Lerman's article has revealed is that we need to explore further what really matters when lawyers lie to clients. It is not only the economic interests at stake, but questions about the meaning of the lawyer-client relationship. General moral rules that permit professionals (or anyone) to lie to avoid causing harm or to benefit either the client or others may be offered as a justification for some forms of deceit, but such formulations are also paternalistic, and it is that paternalism that must be examined and justified.

Because I think Professor Lerman's regulations are fine for the fields they treat but not sufficient for the broader issues about lying, I offer the Golden Rule of Candor for further scrutiny and objections. It too offers a form of paternalism-lawyers deciding what they would want to know if they were in the client's position and thus 
inverts, in a way, the standard notion of client-centered counseling, ${ }^{58}$ and also leaves open the possibility that such decisions will only further reflect lawyer's self-interest. Yet it seems to me to have the kind of common sense and appeal of the original Golden Rule-the kind that we know is moral and correct-just difficult to live up to and even more difficult to put into a professional ethics code.

Professor Lerman's article also hints at those other crucial issues about lying and deception that must be further explored-both empirically and in the possibility of drafting both general rules and specific regulations. Do clients lie to their lawyers? Why? (This may tell us more about clients' views about their lawyers than anything else). How do lies of clients to lawyers alter the responsibilities, if at all, that lawyers have to be truthful to clients (and vice versa)? How does mutual candor affect the notions of reciprocity in the relationship alluded to above?

When do lawyers lie to other lawyers (we know they do thissome of it is justified in the rules ${ }^{59}$ ) and should they? Would my Golden Rule apply there too? The rule would be that a lawyer should be as candid with another lawyer as she would want that lawyer to be with her. I suspect this rule would raise different expectations, if we accept the notion that lawyers currently expect a certain amount of "puffing" and deceit from each other. Could we change this by rule? ${ }^{60}$

We could explore the unthinkable-when and how do lawyers lie to tribunals and judges? Again the rules sanction such behavior by not requiring lawyers to reveal certain facts, such as the presence of witnesses, etc., but only to reveal adverse legal authority. ${ }^{61}$ Do the rules conform to actual practices of deceit or misrepresentation by lawyers or does the incidence of lying track other dividing lines? Should we re-open the question of trying to legislate greater candor among and between actors in the legal system ${ }^{62}$ Can we trust law-

58 See D. Binder \& S. Price, supra note 32, at 147-50.

59 See Model Rules of Professional Conduct Rule 4.1 (1983) ("puffing" permitted); White, supra note 35, at 927 (arguing that it is difficult to apply rules about truthfulness to a lawyer during a negotiation because a negotiator must mislead his opponent).

60 See Schwartz, The Professionalism and Accountability of Lawyers, 66 CaLIF. L. Rev. 669,696 (1978) (recommending a new rule that prohibits a lawyer from "assisting a client to achieve results which would be set aside in judicial proceedings").

61 See Model Rules of Professional Conduct, Rule 3.3 (1983); Model Code of Profiessional Responsibility DR 7-102(A)(5), DR 7-102(A)(3).

62 See Model Rules of Professional Conduct Rules 4.2, 4.3 (Discussion Draft 1980); Hazard, Rectification of Client Fraud: Death and Revival of A Professional Norm, 33 
yers to live by a professional Golden Rule that is contrary to the rewards and incentives offered by an adversary system that prizes zealotry over truth ${ }^{63}$

But these are questions for another day. Professor Lerman has moved us to look into the depths of our deceitful souls and I, for one, think we should continue to pursue this disturbing journey, both for the purifying philosophical and moral aspects of the inquiry and for the possibility of regulating away some of the lawyer's deceit that has come to be so closely associated with the lawyer's role.

Emory L.J. 271, 272, 300 (1984) (proposing a new rule to deal with an attorney's handling of client fraud).

63 See Frankel, The Search for Truth, An Umpireal View, 123 U. PA. L. Rev. 1031, 1039 (1975) (" $[T]$ he gladiator using the weapons in the courtroom is not primarily crusading after truth, but seeking to win."). 
